\title{
Once Again on Mindfulness and Memory in Early Buddhism
}

\author{
Bhikkhu Anālayo ${ }^{1}$ \\ Published online: 16 December 2017 \\ (C) Springer Science+Business Media, LLC, part of Springer Nature 2017
}

\section{Introduction}

In a paper published in the present journal, revised parts of which were subsequently republished in a book on various aspects of early Buddhist meditation, I discussed aspects of the early Buddhist understanding of mindfulness. One of these aspects is the relationship between mindfulness and memory (Anālayo 2016a, p. 1273-1275, 2017a, p. 26-34). Based on the standard canonical definition of mindfulness as a quality related to recollecting and remembering what has been done or said long ago, I argued for the need to make sense of this relationship without going so far as to equate mindfulness with memory.

My proposed solution is that mindfulness enhances memory. When we are mindful, it will be easier to remember later what happened. Moreover, if we are mindful at the time of trying to remember, the information we wish to recollect will more easily come to mind. With this suggestion, I try to make sense of the undeniable relationship drawn in the canonical sources (and later texts) between mindfulness and memory without going so far as to lose out of sight a crucially important aspect of actual mindfulness meditation, which is to stay in the present moment rather than remembering what happened in the past. As mentioned in my original paper, the potential of mindfulness to enhance the ability to remember has been corroborated by recent research in cognitive psychology.

\section{The Question of Memory}

Levman (2017, p. 122) has taken issue with my presentation (and that of others on this topic), stating in the abstract of his paper that

\section{Bhikkhu Anālayo}

1 Numata Center for Buddhist Studies, University of Hamburg, Alsterterrase 1, 20354 Hamburg, Germany
This article argues that the word sati incorporates the meaning of "memory" and "remembrance" in much of its usage in both the suttas and the commentary, and suggests that without the memory component, the notion of mindfulness cannot be properly understood or applied, as mindfulness requires memory for its effectiveness.

Making sense of the relationship between mindfulness and memory is indeed an important topic, wherefore an article dedicated to highlighting this dimension is certainly a welcome contribution. It is also beyond doubt that the practice of mindfulness, as well as other mental operations, requires some form of (semantic and working) memory for their effectiveness. However, that need not imply that mindfulness meditation itself is best conceptualized as inevitably involving some form of remembering, which is sometimes done by those stressing the memory connotation of sati.

In early Buddhist, thought mindfulness is something to be brought into being intentionally. In contrast, memory is required for any meaningful mental activity. Therefore identifying a counterpart to memory in the Pāli discourses requires finding something that is continuously present in the mind. This is why it seems to me preferable to follow a suggestion by Ñānaponika Thera $(1949 / 1985$, p. 69) and relate memory to the aggregate of perception (sañña/想). This aggregate is indeed present in any state of mind, rather than needing to be brought into being through intentional cultivation. Since in early Buddhist thought, such intentional cultivation is required for mindfulness, sati could not in itself serve as an equivalent to memory in its various functions. In fact, Levman (2017, p. 124) cautions that

This paper argues, if not for the equivalence of sati and memory, at least for the centrality of memory and remembering to the denotative and connotative core of the word.

The memory connotation is indeed significant. But this should not be taken to the point of interpreting the meditative cultivation of sati to be always an act of remembering. 


\section{Mindfulness of Breathing}

An example in case is mindfulness of breathing, which Levman (2017, p. 143) sees as a practice of recollection and remembering:

Even the focus on ānappanna, in-and-out-breathing is itself both a recollection-of the air element which the breath is a sub-set of and one of the four elements our bodies are composed of-and an admonition, to leave nothing unquestioned or unexamined about the body or its functioning, to take nothing for granted, and to remember that the body is not-self.

Levman (2017, p. 143n25) supports his statement with a reference to the commentary on the Satipatthāna-sutta. Yet, the commentary he cites offers a gloss on the significance of the expression "contemplating the body," kāāannupassì (Sv III 757). It does not present mindfulness itself as a form of remembering.

In my original publication, I argued that mindfulness of breathing is preferably not conceptualized as a form of remembering (Anālayo 2016a, p. 1274, 2017a, p. 31). Although to remain with the breath requires working memory, this differs from the episodic type of memory described in the canonical definition of sati. Moreover, what such working memory should achieve is remaining mindful of the present breath, not recalling a breath that has happened at an earlier time or dwelling in other memories from the past.

By way of further clarification, the relevant canonical instructions can be taken up for consideration. The first part of the instructions enjoins being with mindfulness established to the forefront (parimukham satim upațhapetvā or 熬念面前), presumably intending that mindfulness is brought to the forefront of one's own mind or field of attention (alternative explanations take this phrase to refer to a physical location for sensing the breath).

Once mindfulness has been established in this way, one should then breathe in mindfully and breathe out mindfully (sato va assasati, sato passasati, with equivalents in 念入息, 念出息 or else 念於內息, 念於外息). Rather than being related to the past, the task described here is very much to stay in the present moment and be aware of the breath as it manifests right now. One should be mindful of the breath coming in or else going out.

This certainly does not concern recalling breathing that has been "done long ago," to use the expression from the canonical definition of mindfulness. Being mindful of the inhalations and exhalations therefore does not require that a practitioner "establishes memory at the forefront of his/her mind," pace Levman (2017, p. 146). Instead, what needs to be established is mindfulness. This is what supports one's remaining aware of the breath, as it manifests in the present moment, not some form of memory of what one has done or said long ago.

The two expressions just discussed are the only parts of the actual instructions where sati itself is mentioned. For the remainder of the practice of mindfulness of breathing, the instructions rather enjoin that one "knows" (pajānāti or 知) or else trains oneself in activities like "experiencing," "calming," and "contemplating" in the full scheme of 16 steps of practice. This terminological shift leaves hardly any room for construing the role of sati itself in relation to the practice of mindfulness of breathing as a remembering of the body as not self or a relating of the breath to the four elements. Such insights and relationships can indeed emerge in the course of practice of the entire instructions on mindfulness of breathing, but the task in the part where sati is explicitly mentioned is just to know that one is breathing in and breathing out.

The same holds for the whole of the Satipatthanna-sutta, where sati itself does not occur in the actual instructions (except for its mention as an awakening factor, where the meditative task, however, is still that one "knows"). In addition to the need to know, these instructions also mention that one "examines" and that one "compares." It is in relation to such activities that the commentary on the Satipatthanna-sutta offers its gloss on how to contemplate the body. The gloss does not concern characteristics of mindfulness itself.

One of the contemplations in the Satipatthanna-sutta and its Chinese parallels enjoin that one "examines" (paccavekkhati/) the anatomical constitution of the body. Another Pāli discourse and its Tibetan parallel qualify the same exercise as a "perception," (sañ̃̄âl'du shes; AN V 109 and D 38 ka 276a, see also Anālayo 2016b, p. 99ff). This fits with the suggestion by Nānapaponika Thera, mentioned above. The task to remember the different anatomical parts and to recall their appropriate evaluation is best assigned to the aggregate of perception. The same holds for the different contemplations assembled in the full scheme of mindfulness of breathing, which feature as another perception in the same discourse. The different activities described in these meditation practices rely on cultivating certain perceptions, which in turn serve to engender liberating insight.

A related point is that the verbs used in the canonical definition of mindfulness, "remembering" and "recalling," do not feature among the activities mentioned in the canonical instructions for satipatthanna meditation and mindfulness of breathing. Had these instructions been concerned with sati performing an act of memory, it would have been quite straightforward to express this directly. Instead of being in itself confined to some form of remembering, sati is what facilitates either recall or else the other activities described in the Satipatthāna-sutta and the instructions on mindfulness of breathing. The insights mentioned by Levman are potential outcomes of the individual contemplations and corresponding perceptions, but they are not presented as something inherent 
in sati itself. Thus, to conceive of sati itself as an activity of "constantly reminding ourselves of the path", as done by Levman (2017, p. 135), risks mistaking the finger for the moon.

The open receptivity of non-interfering mindfulness establishes the mental space for insights of this type to arise, just as it facilitates recalling things from the distant past. But the task of mindfulness in satipațthana meditation is predominantly a passively receptive one by way of providing such facilitation. It is precisely the function of facilitating memory and perceptual associations which enables sati to play this role, such that the insights generated by the activities enjoined in the individual contemplations unfold, but this role remains a passively receptive one.

\section{Mindfulness and Wisdom}

Levman (2017, p. 124), however, sees the cultivation of wisdom as an integral dimension of sati itself, arguing that, in relation to the canonical definition of mindfulness,

What Anālayo has failed to take into consideration is the Buddha's statement that the one who possesses sati $(\operatorname{satim} \bar{a})$ is "endowed with the highest memory and wisdom" (satimā hoti paramena satinepakkena samannāgato); sati is not any memory-semantic, episodic, or otherwise-but that special faculty which is also united with wisdom.

The standard canonical definition of mindfulness and its implications are the main point of departure of my own exploration (Anālayo 2016a, p. 1273 and the full text in Anālayo 2017a, p. 26n16). In the case of an occurrence of this definition in the Anguttara-nikāya (AN IV 111), the Pāli expression paramena satinepakkena samannāgato has a counterpart in the relevant Chinese parallel in "being endowed with right mindfulness,” 成就正念 (T I 423a). Thus the term that allegedly brings in wisdom is not reflected in this discourse. In fact a definition of the faculty of mindfulness as related to memory in another Chinese discourse collection does not have any counterpart to the entire phrase paramena satinepakkena samannāgato (T II 779b). Elsewhere the Chinese Ägamas tend to refer to the four satipatthanas when defining the faculty of mindfulness, rather than to remembering what has been done or said long ago.

Clearly there is no consensus among early Buddhist discourses regarding the phrase paramena satinepakkena samannāgato. It would indeed be preferable not to make claims regarding "the Buddha's statement" based just on the Pāli discourses. What we have at our disposal for reconstructing early Buddhist thought are textual remains of different oral transmission lineages, none of which offers us a definite record of what the historical Buddha actually said.

Besides not being reflected in the Chinese parallels mentioned above, the phrase paramena satinepakkena samannägato need not be taken as implying that one who is mindful is "endowed with the highest memory and wisdom". Here is how Bhikkhu Bodhi (2012, p. 1078) renders the entire definition of sati in the Añguttara-nikāya discourse (AN IV 111):

A noble disciple is mindful, possessing supreme mindfulness and alertness, one who remembers and recollects what was done and said long ago.

For Bhikkhu Bodhi, the phrase refers to "supreme mindfulness and alertness," rather than to "highest memory and wisdom." The canonical definition of mindfulness occurs in several Pāli discourse collections. Translations of these passages by accredited scholars understand satinepakkena as relating mindfulness to "perspicacity" (Rhys Davids 1921, p. 247), a being "richly stored" (Chalmers 1926, p. 256), "discrimination" (Hare 1955, p. 73; Horner 1970, p. 22; Woodward 1930, p. 174), "capacity" (Walshe 1987, p. 508), "prudence" (Cox 1992/1993, p. 78), "intellect" (Gethin 1992, p. 36), "skill” (Ñāṇamoli 1995/2005, p. 463), and "discretion" (Bodhi 2000, p. 1672). None of these employs the term "wisdom". In fact the standard term for wisdom is pañ $\tilde{a} /$, a sense not necessarily carried by nepakka.

In the present context, wisdom does indeed not seem to be relevant. At times we might recall something rather silly said or done a long time ago. This is a case of "remembering and recollecting what was done and said long ago," but such memory is hardly a matter of being automatically "united with wisdom." Such recollection may even call up reactions that are the very opposite of wisdom, in the way this is understand in early Buddhist thought. In sum, the ability to remember something done or said in the distant past does not on its own entail the presence of wisdom.

In fact, even remembering words of wisdom said long ago is not an intrinsic dimension of sati, given that the discourses clearly recognize wrong forms of mindfulness. These could hardly involve a faculty united with wisdom. Nevertheless, Levman (2017, p. 128) argues that

In other words, sati is not a passive act of receptive awareness, but requires memory of the Buddhadhamma to motivate and catalyze transformation (Thanissaro 2012, p. 113-115).

The reference given points to what to my knowledge is indeed the main source where mindfulness is conceptualized in the way argued by Levman, namely in the writings by Bhikkhu Thānissaro. Apart from these writings, which I am afraid confuse the functions of mindfulness and of clear comprehension 
respectively, the sources of early Buddhism do not imply that mindfulness itself is invariably an act of remembering the Buddhadhamma. The case of being mindful of breathing in and out suffices to confirm this point. It needs hardly any acquaintance with the teachings of a Buddha to be able to discern the difference between inhalations and exhalations.

\section{Sati and Smrti}

Another argument raised by Levman (2017, p. 122) concerns the historical antecedent in the ancient Indian setting to the term sati, as the relevant term smrti conveys the senses of memory and sacred tradition:

Since the Buddha was familiar with the Brahminical teachings, including the six Vedāngas (linguistic analysis, etymology, etc.) which are part of the smrti tradition, it is unlikely that he would have used the vernacular form of the word (sati) in a way inconsistent with its heritage.

Now the sense of smrti as a body of sacred tradition is to my knowledge not reflected in the usage of sati in the early Buddhist discourses, leaving only the other nuance of memory. This is indubitably a recurrent feature in the discourses (and later texts), but it does not follow that the Buddha could not have developed his own usage of a term that was current at his time. In relation to several Brahminical concepts and ideas, the discourses reflect at times substantial re-interpretations attributed to the Buddha. This is recognized by Levman (2017, p. 125), who sees teachings of the Buddha to be "directly responding to Brahmanical notions" and in relation to smrti comments that

in the Prakrits including Pali it took on the additional connotation of "lucidity of mind", which it does not have in Sanskrit. In his B[uddhist] H[ybrid] S[anskrit] dictionary, Edgerton defines it exclusively in the second meaning: "mindfulness, (full) consciousness or awareness," although he does say that [it] is "hardly distinguishable from some aspects of Skt. id.”.

Not only the usage in Buddhist Sanskrit offers such significant indications. In a study on the meaning of the root $s m r$ in Vedic literature, Klaus (1993, p. 77) critically examines the assumption that, due to its relation to smrti, the term sati should denote just remembrance or memory, pointing out that

Mostly, however, sati does not stand for the mental faculty to recall to mind, to visualize something that happened in the past, someone or something that is not present, but to notice, to become or be aware of something actually happening, an actual feeling or thought, a present person or thing. In these cases sati must be rendered by 'attention' or 'awareness' or 'mindfulness.'

Klaus (1993, p. 78f) further argues that "from an etymological point of view, 'attention, awareness' is not necessarily a new connotation of sati attached to it at the rise of Buddhism, but one that might have belonged to it all along," followed by noting instances in the Rgveda where "smr and its derivatives denote the becoming or being aware of something actually happening or the directing of one's attention to an expected event."

Levman (2017, p. 122) in fact recognizes that "sati is a polysemous word whose semantic field extends beyond mere memory." In sum, then, although "the notion of memory is central to the denotative and connotative core" (id.), the early Buddhist usage of the term need not be confined to modalities of remembering. The case of mindfulness of breathing in and out again serves as a handy illustration.

\section{Mindfulness and Buddhism}

A passage among the long discourses describes how a previous Buddha descended into the womb of his mother. He is depicted as being with sati and clear comprehension already at the time of his conception (DN II 12). A Chinese parallel describes him as being with right mindfulness 正念 and without confusion (T I 3c); no such qualification is found in two other parallels.

Levman (2017, p. 131) understands the Pāli commentary on this passage as implying that the descent into the mother's womb took place with memory and wisdom. Yet the commentary just explains that sati stands here simply for sati (a gloss that says nothing really about its implications), and clear comprehension, sampajāna, refers to "knowledge," ñanna (Sv II 427). It seems a far-stretch to render $\tilde{n} \bar{a} n a$ as "wisdom" and the assumption that sati here must refer to memory is not warranted by the context, nor does it receive support from the Chinese parallel. The issue at stake in the Digha-nikāya version and its Dìrgha-ägama parallel is not recalling something from the past, but the feat of being aware even at the time of being conceived.

The significance of the description in these two discourse is not the establishing of a relation between this feat and memory as well as wisdom, but rather that tradition did not consider sati as something discovered by a Buddha only with awakening. From this viewpoint, mindfulness is not something distinctly Buddhist, in contrast to the teachings that are considered an outcome of the awakening realization of a Buddha.

A similar depiction can be found for the present Buddha, who in another Pāli discourse is also on record for being with mindfulness at the time of his conception (MN III 119). The 
Chinese parallel speaks of him descending into his mother's womb "knowingly," 知, which probably intends a similar condition of full awareness during conception (T I 470a).

Whereas the quality of mindfulness as such is not considered something inherently Buddhist, this changes once it comes to the function of mindfulness as one of the awakening factors. These are considered to be indeed something only revealed by a Buddha (SN V 99 and T II 194a). In other words, it is not mindfulness as such, but rather its practice in the form of the four satipatthannas-leading up to a cultivation of the awakening factors-that should be considered a distinctly Buddhist contribution. What a Buddha discovers and teaches to others is the harnessing of mindfulness to progress to awakening.

The discourses indeed relate the Budda's disclosing of the four satipatțānas to the time soon after he had reached awakening (SN V 167, T II 322a, T II 410b, and T II 494a). In this way, the four satipațthānas can be viewed as an outcome of the Buddha's own progress to, and attainment of awakening, which made him realize the potential of mindfulness for progress to liberation (Anālayo 2017b, p. 100-103).

This potential lies in the open receptivity of wellestablished mindfulness, which facilitates memory as well as meditation. The significance of the memory nuance can in turn be understood to convey a point of considerable practical importance: mindfulness of what happens in the present moment should be undertaken with the same kind of attitude one would bring to anything that one later needs to remember.

Imagine the type of attitude of keen interest and open receptivity one would bring to a situation of which one is to give a detailed report later, but without being able to rely on note taking or digital recording equipment. It would be crucial to avoid getting caught up in minor details and tangential associations, as well as to maintain a balanced attitude of unbiased observation rather than succumbing to emotional reactions. Such qualities are precisely what mindfulness meditation tries to inculcate.

In an oral society, the time of listening to some teaching is an exemplary situation calling for a mindful attitude, since lacking written or digital recording techniques, one is entirely dependent on properly taking in what is being said. Otherwise, at a later time, one will be unable to reflect on it or tell others about it. Such a situation would be a self-evident example in the ancient Indian setting for illustrating central characteristics of mindfulness. Thus, the memory connotation of sati is indeed of considerable significance for actual mindfulness practice, by way of clarifying that mindfulness meditation requires the same open receptivity and alertness that one would bring to a situation to be remembered later.

\section{Conclusion}

In early Buddhist thought, sati is not invariably a matter of remembering something from the past. In the context of satipatthāna meditation, it rather stands for mindfulness of what is present. The insightful input that endows the cultivation of mindfulness with its awakening potential is better related to other terms that in the canonical instructions accompany sati, such as "clear comprehension," or the injunctions that one should "know," "examine," and "compare". Based on the input of formerly learned concepts, provided with the help of the aggregate of perception, these activities enable the insightful processing of the raw data that has become available through well-established mindfulness. Understood in this way, sati facilitates through its presence; in other words, mindfulness is not so much something to be done, but much rather something to be.

Acknowledgements I am indebted to bhikkhunī Dhammadinnā and Bryan Levman for commenting on a draft version of this article.

Abbreviations AN, Añguttara-nikāya; D, Derge edition; DN, Dīghanikāya; MN, Majjhima-nikāya; SN, Samyutta-nikāya; Sv, Sumañgalavilāsinī; T, Taishō edition

\section{References}

Anālayo, Bh. (2016a). Early Buddhist mindfulness and memory, the body, and pain. Mindfulness, 7, 1271-1280.

Anālayo, Bh. (2016b). Mindfully facing disease and death, compassionate advice from early Buddhist texts. Cambridge: Windhorse Publications.

Anālayo, Bh. (2017a). Early Buddhist meditation studies. Barre: Barre Center for Buddhist Studies.

Anālayo, Bh. (2017b). A meditator's life of the Buddha. Cambridge: Windhorse Publications.

Bodhi, Bh. (2000). The connected discourses of the Buddha, a new translation of the Samyutta Nikāya. Boston: Wisdom Publications.

Bodhi, Bh. (2012). The numerical discourses of the Buddha, a translation of the Anguttara Nikāya. Boston: Wisdom Publications.

Chalmers, R. (1926). Further dialogues of the Buddha, translated from the Pali of the Majjhima Nikâya, vol 1. London: Oxford University Press.

Cox, C. (1992/1993). Mindfulness and memory: the scope of smrti from early Buddhism to the Sarvāstivādin Abhidharma. In J. Gyatso (Ed.), In the mirror of memory, reflections on mindfulness and remembrance in Indian and Tibetan Buddhism (pp. 67-108). Delhi: Sri Satiguru.

Gethin, R. (1992). The Buddhist path to awakening: a study of the bodhipakkhiyā dhammā. Leiden: E.J. Brill.

Hare, E. M. (1955). The book of the gradual sayings, part IV. London: Pali Text Society.

Horner, I. B. (1970). The collection of the middle length sayings (Majjhima-Nikāya), vol. II. London: Pali Text Society.

Klaus, K. (1993). On the meaning of the root $s m r$ in Vedic literature. Wiener Zeitschrift für die Kunde Südasiens, 36, 77-86.

Levman, B. (2017). Putting smṛti back into sati (putting remembrance back into mindfulness). Journal of the Oxford Centre for Buddhist Studies, 13, 121-149.

Ñānamoli, Bh. (1995/2005). The middle length discourses of the Buddha, a translation of the Majjhima Nikäya. Boston: Wisdom Publications.

Nānaponika Th. (1949/1985). Abhidhamma studies, researches in Buddhist psychology. Kandy: Buddhist Publication Society. 
Rhys Davids, T. W. (1921). Dialogues of the Buddha, translated from the Pali of the Digha Nikāya, part III. London: Oxford University Press. Thānissaro, Bh. (2012). Right mindfulness, memory \& ardency on the Buddhist path. California: Metta Forest Monastery.
Walshe, M. (1987). Thus have I heard; the long discourses of the Buddha. London: Wisdom Publications.

Woodward, F. L. (1930). The book of the kindred sayings (SamyuttaNikāya) or grouped suttas, part V. London: Pali Text Society. 